\title{
Influence of in-store and out-of-store creative advertising strategies on consumer attitude and purchase intention
}

\author{
Ardalan Sameti ${ }^{1}$ (iD), Hamidreza Khalili ${ }^{2}$ (D) \\ 'Young Researchers and Elites' Club, Central Tebran Branch, Islamic Azad University (Iran) \\ ${ }^{2}$ Young Researchers and Elites' Club, Shabryar Branch, Islamic Azad University (Iran) \\ ardalan.sameti@gmail.com,razshabha@yahoo.com
}

Received January, 2017

Accepted June, 2017

\section{Abstract}

Purpose: With regard to the fact that people usually try to avoid repetitive and boring advertisements, creativity as the heart of advertising effectiveness has a significant role in drawing their attention. On this basis, the present study attempts to evaluate the influence of creative advertising strategies by comparing "in-store" and "out-of-store" creative advertisements.

Design/methodology: This research has been conducted in Tehran (capital of Iran) and 588 volunteers randomly participated in the survey so as to examine the consumers' attitude/behaviour towards the advertised brand, advertised product, and purchases intention exposing creative in-store and out-of-store advertisements. In the current study, creative "endof-aisle display stands" in grocery stores/supermarkets represent in-store advertising media, and creative "TV commercials" represent out-of-store advertising. Furthermore to examine the hypotheses, one-sample t-test and paired sample t-test were used.

Findings: The results show that creative out-of-store advertising has influence primarily on attitude towards the advertised brand, then on attitude towards the advertised product, and 
finally on the purchases intention. On the other hand, creative in-store advertising, firstly has influence on the purchase intention, then on attitude towards the advertised brand, and lastly on attitude towards the advertised product. The findings provide important insights to the formulation of strategic marketing/advertising and would pave the related innovative ways to capitalize on strategic opportunities.

Originality/value: The study is the first survey comparing the effectiveness of in-store and out-of-store creative advertising in order to find out a strategic marketing/advertising solution.

Keywords: Advertising, Creative advertising, In-Store advertising, Out-of-Store advertising, Advertising strategy, Marketing strategy, Branding strategy, Consumer attitude, Purchase intention

Jel Codes: M37, M31, M30

\section{Introduction}

Consumers oftentimes try to avoid advertisements. Because they found advertising repetitive and boring (Hutter, 2015). Thus, devising the new creative advertising strategies gaining and holding consumers' attention is necessary for manufacturers and retailers in order to raise the advertising effectiveness, subsequently, increase the sales amount.

Creativity as the heart of advertising effectiveness (Bernardin et al., 2008; Lee \& Hong, 2016; Baack, Wilson, Van Dessel \& Patti, 2016) has multiple roles in terms of its ability to extract the most impressive message strategy from the firm's strategies and influence the message persuasion. For instance, it can act as a mechanism to encourage deeper message processing and it also can generate an emotional response choosing the most appropriate (creative) message and conveying method for the market including customers and consumers (Baack et al., 2016). Clearly then, creativity has a positive impact on ad processing and response (effectiveness) (Baack et al., 2016; West, Kover \& Caruana, 2008). Several studies indicate that creative advertisements definitely, owing to their attention-getting qualities, are consequently influential in promoting deeper levels of message processing than noncreative ads (Baack et al., 2016; Smith, Chen \& Yang, 2008; Maclnnis \& Jaworski, 1998; Lee \& Hong, 2016; Sasser \& Koslow, 2008). By being innovative stimuli, viewers usually want to solve the puzzle (Baack et al., 2016). Creative messages and advertisements influence them by being better attended, 
better remembered, and seen more favorably (Baack et al., 2016; Smith, MacKenzie, Yang, Buchholz \& Darley, 2007; Till \& Baack, 2005; Smith \& Yang, 2004; Lee \& Hong, 2016). Thus, creative ads lead to more favorable attitudes and increase the probability of a series of behaviours such as purchase intention, which are highly significant advertising outcomes and strongly related to add effectiveness (Baack et al., 2016; Smith et al., 2007; Smith et al., 2008; West et al., 2008).

According to the aforementioned arguments, the high influence of creativity on psychological and unconscious thought-processes is undeniable (Baack et al., 2016). Therefore, this paper purpose is to focus the influence of in-store and out-of-store creative advertising (creative strategies for ads' ideas and executions) on consumers' attitude towards the advertised brand/product, and behaviour/purchase intentions, also attempts to ascertain and compare the effectiveness of in-store and out-of-store advertising, which has not been considered in related literature, so the present paper aims at filling this void. Since advertising research lacks enough empirical and practical studies related to these sections, compering the in-store and out-of-store advertising media and their effectiveness could be a key factor for both companies and advertising agencies in order to come up with more creative and more effective strategies for designing marketing and in particular, advertising campaigns. This issue is highly important psycho-cultural fact from the standpoint of the advertisement outcomes optimization, the outcomes such as consumer's attitude towards the advertising, the advertised brand/product, and their behaviour/purchase intention. That is so substantial for devising more successful branding and promotional marketing strategies. Additionally, it should be mentioned that the consumers' positive attitude towards the creative ads would not be investigated in this research, since it has completely proven by several previous authentic studies. Accordingly, in this paper the previous research in relation to the positive effect of creativity on consumers' attitude towards the ads have been propounded. Findings of this current survey from the standpoint of intensity level of influence show that out-ofstore (creative) advertising has influence primarily on attitude towards the advertised brand, then on attitude towards the advertised product, and finally on the purchases intention. On the other hand, instore (creative) advertising, firstly has influence on the purchase intention, then on attitude towards the advertised brand, and lastly on attitude towards the advertised product. These results would assist (promotional) marketing strategists to maximize the advertising effectiveness selecting the most proper medium to present the ads. 


\section{Literature review}

\subsection{Creativity and advertising effectiveness}

Creativity denotes a new solution to a problem, a new method or device, or a new artistic object or form. Besides, advertising is a fundamental form of communication between firms and their customers that must be precisely managed maximizing the sale amount (Smith \& Yang, 2004).

Although according to Smith and Yang, several factors such as resources, the amount of space, time, budget and so forth, play remarkable roles in advertising effectiveness (Smith \& Yang, 2004). In the same way, Zenetti and Klapper have argued assessing the advertising effectiveness, which ultimately is led to consumers' purchase decisions, is an important yet very complicated, because it depends on both current and past marketing efforts (Zenetti \& Klapper, 2016). Creativity (regardless of abovementioned criteria) has been recognized as one of the most significant concepts in the design and development of effective advertising (Baack et al., 2016; Smith \& Yang, 2004; Yang \& Smith, 2009; Lehnert, Till \& Ospina, 2014; West et al., 2008; Maniu \& Zaharie, 2014). Broadly speaking, advertising effectiveness measured by the ad ability to brand recall and its likeability (Hartnett, Romaniuk \& Kennedy, 2016). Accordingly, creative advertising enhances recall, brand/product attitude, and purchase intent, which are defined as ad effectiveness (Till \& Baack, 2005). In consumer advertising, particularly, creativity often used to increase advertising effectiveness. Thus, this is clear that creativity generates higher levels of advertising effectiveness (Baack et al., 2016; Smith \& Yang, 2004; Yang \& Smith, 2009; West et al., 2008; Bernardin et al., 2008; Lee \& Hong, 2016; Maniu \& Zaharie, 2014), making the ad more productive and capable to obtain its goals (Smith \& Yang, 2004). On the contrary, in another research done by Baack, Wilson, and Till, they finally have alleged that creativity had no effect on environmental advertising effectiveness, where consumers often are in a distracted state, such as in airport terminal (Baack, Wilson \& Till, 2008). That cannot be fully acceptable claim, since this result is vastly dependent on the several factors, and ultimately we can only say that in these situations creativity role decreases caused by people anxiety and reducing the level of their attention. Anyway in the present research, these sorts of ads have taken into account as the out-of-store advertising.

In consideration to this fact that most of the related research indicates creative messaging increased the effectiveness of advertising, in academic papers, creative message as the creative advertising foundation must be included two elements "novel" and "relevant" (Smith \& Yang, 2004; Smith et al., 2008; Baack et al., 2008; Ang, Lee, \& Leong 2007; Lehnert et al., 2014; Lee \& Hong, 2016; Maniu \& Zaharie, 2014). Thereby, novelty and relevance of the message are the main factors in innovative advertisement which 
can transfer more pleasure to customers. In particular, novelty is mostly seen as humorous, entertaining and enjoyable theme in advertising (Smith \& Yang, 2004; Smith et al., 2008). Entertainment draws viewers' attention to the ad message (Maniu \& Zaharie, 2014). Additionally, humor; sentimental images, sex appeal, emotional music, and so on, have been taken into account as the ad creativity traditional techniques (Yang \& Smith, 2009). Novelty refers to a different implementation in terms of being new, unique, unusual, surprising, imaginative or divergent (Baack et al., 2016; Smith \& Yang, 2004; Smith et al., 2007; Smith et al., 2008; Baack et al., 2008; Lehnert et al., 2014; Ang et al., 2007; Maniu \& Zaharie, 2014). According to research, five unique divergence factors are originality (uniqueness), flexibility (switching from one idea to another), synthesis (connecting unusual items together), elaboration (providing unexpected details to be sophisticated), and artistic value (striking visual/verbal elements) (Smith et al., 2007; Smith et al., 2008; Yang \& Smith, 2009). Several studies indicate that people have a need for closure and interpret, thus, are more enthusiastic about ambiguous and unusual stimuli. Psychology of aesthetics suggests that ambiguous or incongruent stimuli generate positive reactions. Indicating the consumers' desire to decode the message, that is a pleasurable feeling (Smith \& Yang, 2004; Smith et al., 2008; Yang \& Smith, 2009). As a final word, creative ad increases the consumers' processing motivation, and will be transferred to their long-term memory (depth of ad processing) (Smith \& Yang, 2004; Smith et al., 2008; Wilson, Baack \& Till, 2015; Baack et al., 2008; Lee \& Hon g, 2016) and results in higher recall, additionally, more favorable attitudes, also positive feelings towards the ad, and whereby the advertised brand/product, besides that, purchasing inclinations (Baack et al., 2008; Ang et al., 2007; Till \& Baack, 2005; Lehnert et al., 2014; Hartnett et al., 2016; Bae, Wright \& Taylor, 2001; Hutter, 2015; Janssens \& Pelsmacker, 2005). Moreover, relevance or connectedness in the eye of the ad's creative element, defines as being meaningfully tied to the product (Baack et al., 2016; Baack et al., 2008; Lehnert et al., 2014; Ang et al., 2007). As such, according to Smith and Yang, creative advertising must be logical, meaningful, and related to the brand/product and its consumers' type (Smith \& Yang, 2004). On a lighter note, the novel and innovative element should be relevant to the message, product or service, and brand so that it has identifiable meaning (Baack et al., 2016; Baack et al., 2008). Relevance in the view of advertising is classifiable to "brand/product or message-related" (ad's idea relation to the type of brand/product or message, even the consumers) and "executionrelated" ads (ad's totality relation to way of the execution). Brand/product or message-related ads generate deep processing and produce more desirable "brand responses" and would be resulted in higher brand cognitions, brand attitudes, and purchase intentions (which is usually the focus point in these types of studies). On the other hand, execution-related ads produce more favorable "ad responses" and would be resulted in higher ad cognitions and ad attitudes (Smith \& Yang, 2004; Smith et al., 2007; Smith et al., 2008; Yang \& Smith, 2009). 
To conclude, ad creativity is defined as a function of divergence and relevance, the elements that increase the ad effectiveness as well (Smith \& Yang, 2004; Smith et al., 2007; Smith et al., 2008; Baack et al., 2008; Ang et al., 2007; Lehnert et al., 2014; Lee \& Hong, 2016; Maniu \& Zaharie, 2014).

\subsection{Creative advertising strategies}

Advertising creativity can be a successful approach for business advertising strategy. As it was mentioned previously, creativity is an important determinant of advertising effectiveness. Consequently, well-planned creative strategy and implementation are essential elements in the development of advertising. Creative advertisements lead to more focus on ad content and messaging strategy, so as to increase the customers' engagement/involvement with the message and strategy (Baack et al., 2016; Lee \& Hong, 2016).

Although, some studies allege that creative ads do not always lead to more favorable brand/product attitude and purchase intention (Ang et al., 2007), it is clear that creative ads are able to generate stronger shifts in attitudes towards the ad, the brand/product, and behavioural intentions (Baack et al., 2016; Smith et al., 2008; Till \& Baack, 2005). Highly creative ads increase open-mindedness, curiosity, and positive affect producing higher levels of viewing intentions and brand/product purchase intentions (Baack et al., 2016; Yang \& Smith, 2009; Bernardin et al., 2008). Creativity is widely significant for its ability to seize attention and to convey information in an entertaining or challenging way (West et al., 2008). At this level and for this purpose, creative ads must to be more entertaining, interesting, or enjoyable. These emotional responses are subjective marketing elements that influence ad responses and accordingly the decision-making process. In consumer markets particularly, creative advertising campaigns are known to draw attention, generate interest, and enhancing brand awareness. From this point of view, effectiveness means having likable ads can result in greater brand awareness, more favorable attitudes towards the brand/product, and stronger behavioural/purchase intentions. In the meantime, the benefits of ad creativity have also been found to be long-lasting, with the cognitive advantages increasing the longer intervals between advertising exposures (Baack et al., 2016; Till \& Baack, 2005). Moreover, creative ads reduced customers' resistance to persuasion by generating positive attitudes towards the brand/product and purchase intentions (Baack et al., 2016; Smith et al., 2008; Till \& Baack, 2005; West et al., 2008; Lee \& Hong, 2016; Maniu \& Zaharie, 2014). On this basis, the more favorable the attitude towards ads is, the more credible the brand becomes. On the other hand, positive attitude towards ads and brand/product is not necessary lead to the intention to purchase. However, 
the research indicates it usually generates intention to buy the advertised brand/product (Maniu \& Zaharie, 2014).

In a word, we are faced with two main targets related to ad effectiveness that creative ad strategies must be focused on them, "brand" and "purchase intention". Although, based on several research results, consumers who are wholly unaware of the brand go through seven steps: awareness, knowledge, liking, preference, conviction, and purchase (Smith et al., 2008).

\subsubsection{Brand}

Brand is a perception that its major duty is to ease consumers to recognize that among the competitive set. Moreover, brand elements (brand identity) are included the brand name (trade name), logo and/or logotype (trade mark), symbols, packaging, shapes, colours, fonts, characters, spokes-characters, slogans, jingles, sounds, mascots, and/or even styles of advertising. That all should increase the brand recall (Hartnett et al., 2016).

Creative advertising and messaging apart from increasing the level of general awareness and comprehension can directly generate more favorable attitudes towards the advertisement and brand. Therefore, would enhance the firm's brand equity as a result of emotional content for enhancing brand awareness and brand attitudes (Baack et al., 2016; Smith \& Yang, 2004). From another point, brand's equity as the financial value (added value) of a brand to the firm positively influences consumers' perceptions, and subsequently, their brand buying behaviours. In other words, advertising is a significant marketing communication tool influencing brand equity dimensions using marketing mix elements (4Ps and/or 7Ps). These dimensions from consumers' point of view assess as the awareness, attitudes, perceived quality, associations, attachments, and loyalty towards a brand. So in brief, attitudes towards the advertisements play a major role influencing brand equity (Buil, Chernatony \& Martínez, 2013).

Recent research using eye-tracking technology also shows that ads deemed original in design, surprising, and unique have a strong correlation with attention increasing to the ad, resulting in improved brand image and brand reputation. Furthermore, innovative ads generated higher levels of fondness to the brand and above all, seeking in extra information about the brand and product (Baack et al., 2016). Other research similarly shows that effective advertising generates invisible (intangible) asset such as 
reputation, brand image, and corporate image for the firms. Besides, brand equity generates competitive advantage for companies (Besana \& Clavenna, 2012).

All in all, advertising as a main tool of branding activities can reduce risk perceptions and rationalize the buying decisions increasing the brand awareness and use of emotional appeals (Baack et al., 2016). In addition, brand must be able to compete with others to be noticed and remained in customers' memory with the advertising aid (Hartnett et al., 2016). With respect to this fact that brand reputability can positively affect total revenues and consequently, profitability of the firm, branding activities derived from advertising and other promotional tools are considered as a strategic priority and investment (Besana \& Clavenna, 2012). That is to say, branding strategies eventually influence on the purchase intention (Smith \& Yang, 2004).

In branding literature, brand awareness is one of the main components of brand loyalty and brand equity. It is the major reason behind consumer repeat purchase decisions (simple recognition of a brand name and/or recall), in other words, the strength of a brand's presence in the consumer's mind. Brand equity products reflect higher market share growth, particularly when supported with reminder advertising, and brand loyalty or brand preferences means the buyer may prefer to buy a specific product from a particular supplier for a variety of reasons. Moreover, brand attitude denotes where the first element of "brand loyalty" is formed (Umit Kucuk, 2011). Furthermore, brand image is defined as the total consumers' perceptions (symbolic, functional, emotional, and reasoned brand beliefs/attitudes) to a specific brand (Islam \& Rahman, 2016). In other words, brand image means as the set of brand associations in consumers' memories about a particular brand. Brand associations also, reflect the meanings of brands to consumers through linking product/service information to the brand nodes existing in consumers' minds (Wang \& Yang, 2010).

\subsubsection{Purchase intention}

Buying behaviour literature represents a complicated process with internal, external, sociocultural, and demographic (e.g. gender, age, education, and income) factors and their impact on the decision making process (Clement, 2007; Vianelli, Dianoux, Domanski \& Herrmann, 2007), although, in terms of advertising impact, new research argues that advertising effectiveness ultimately must be led to consumers' purchase decisions (Zenetti \& Klapper, 2016; Hartnett et al., 2016). As a mechanism for message processing, as it was noted in previous parts, creativity draws more attention to the ad and promotes greater interpretation of message arguments, leading to more favorable attitudes and higher 
levels of purchase intentions. Several studies show that creative advertisements increase the probability to purchase (Baack et al., 2016; Smith et al., 2008; Yang \& Smith, 2009; Till \& Baack, 2005; Lee \& Hong, 2016) as an ultimate result of other mentioned factors.

\subsection{In-store and out-of-store advertising}

Advertising media types are vastly varied and usually are classified to indoor and outdoor advertising, such as print media (e.g. newspaper, magazine, posters), word of mouth, television, radio, the Internet ads, email, mobiles, applications, virtual catalogues, salespersons, and a lot of other new media that have altered marketing techniques and strategies (Ahn, Lee, Lee \& Paik, 2012; Areni \& Miller, 2012; Wilson et al., 2015; Kim, Lee, Mun \& Johnson, 2016; Vianelli et al., 2007) by the improvement of the cutting edge digital technology and creative graphic design. Some of these media namely are billboards, panels, free-standing panels, rackets, advertisement towers, mega lights, electric posts, city furniture, and so on that are among the innovative methods are giving a new impulse to advertisement (Akören, 2015; Koeck \& Warnaby, 2014), moreover, are innovative ways to capitalize on strategic opportunities (Kim et al., 2016).

According to many studies, consumers often try to avoid being influenced by advertisements. Thus, finding the new unconventional (innovative/creative) advertising strategies gaining and holding consumers' attention is vital for manufacturers in order to raise the advertising effectiveness (Hutter, 2015).

Research shows that design elements and many other factors including banner size, material, visual aspects, colors, use of animation, presence of image, and so forth influence indoor/outdoor advertising effectiveness (Song, Xu, Techatassanasoontorn \& Zhang, 2011; Hutter, 2015). Yet, this paper focuses the influence of in-store and out-of-store creative advertising (creative strategies for ads' ideas and executions) on consumers' attitude towards the advertised brand/product, and behaviour/purchase intentions, also attempts to ascertain and compare the effectiveness of in-store and out-of-store advertising, which has not been considered in related literature, so the present paper aims at filling this void. 


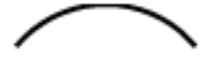

Ad media



Out-of-store Creative Ads

In-store Creative Ads
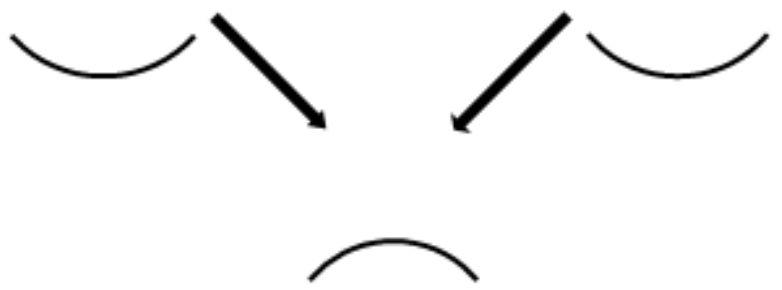

Creative Ads Outcomes

(Effectiveness)

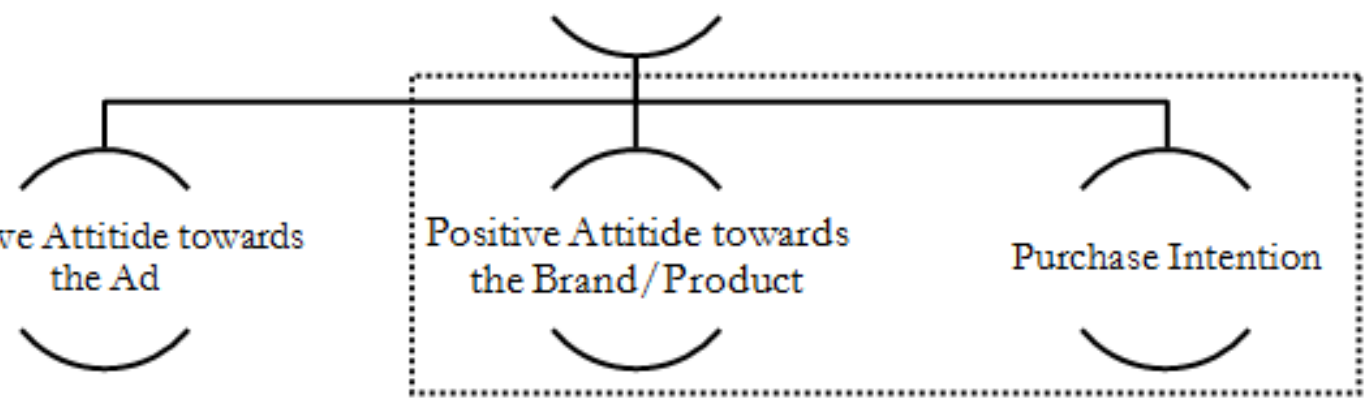

Figure 1. Creative Advertisement Effectiveness (Authors' own findings based on reviewing the literature) 


\subsubsection{Out-of-store advertising}

Outdoor/ambient (out-of-store) advertisements are placed in areas where customers are located in their everyday lives and do not expect to encounter advertising (Jurca \& Madlberger, 2015).

With increased exposure to advertising, consumers are getting fed up with marketers' persuasion techniques (particularly the out-of-store advertising). Hence, new creative strategies are required to enhance the advertising effectiveness. Ad effectiveness depends on the degree to which customers process the information that is being conveyed in a message, on a lighter note, customers' awareness, perceptions, attitudes, and intentions towards a specific ad, brand, and product (Jurca \& Madlberger, 2015).

Research indicates creativity (creative idea and execution) influence the brand memorizing for outdoor (out-of-store) advertising (Wilson et al., 2015; Hartnett et al., 2016). Based on Jurca and Madlberger (2015), advertising effectiveness on the level of consumers' mind-set, in the long run have an impact on sales. Luxton and Drummond (2000) similarly, suggest that outdoor (out-of-store) advertising is largely used for branding support and not primarily as a tool to increase product purchases in the short run. Many outdoor/ambient (out-of-store) advertising campaigns also seek to strengthen consumers' outlooks instead of increasing sales in the short run, however, should show a positive impact on sales in the long run (Jurca \& Madlberger, 2015).

Although, the previous related literature does not hint directly on out-of-store advertising, whereupon, it can be concluded that outdoor and out-of-store advertising have a stronger effect on brand/product attitude than purchase intention. Clearly then, out-of-store advertising denotes all the advertising media that consumers are dealing with out of the retail stores. A wide media range from the television commercials (indoor) to the billboards (outdoor).

H1: General set of out-of-store creative advertisements have a stronger positive effect on the brand/product awareness and attitude than purchase intention.

H2: General set of out-of-store creative advertisements have a stronger positive effect on the brand awareness and attitude than product awareness and attitude. 


\subsubsection{In-store advertising}

Store is a place where the consumers enter with information, look around, think about

the product, evaluate what to do (between alternative brands/products, money, time, and so forth), and finally make a decision to purchase (Vianelli et al., 2007).

Reviewing the related literature indicates the significant role of visual attention (e.g. packaging design, signage, lighting, store layout, merchandising, shopping carts, and shopping bags, particularly in this study, to advertise a specific brand/product) in in-store (brick and mortar stores) advertising. Accordingly, people concentrate their sight on where they can find something new or interesting (Clement, 2007; Hutter, 2015; Sigurdsson, Engilbertsson \& Foxall., 2010).

Studies indicate pleasure (hedonic value) induced by store environment and atmosphere (ambient factors such as lighting, scent/aroma, music, layout/assortment, signage, and effectiveness of salespersons) appears to be a strong cause of consumers spending extra time in the store and spending more money than intended (Fam, Merrilees, Richard, Jozsa, Li \& Krisjanous, 2011; Mohan, Sivakumaran \& Sharma, 2013). Thus, it should be taken into consideration that in-store marketing strategies are more important than external marketing in retailers' promotion (Fam et al., 2011; Gabrielli \& Cavazza, 2014).

Several studies show that around two-thirds of brand/product decisions (impulse/unplanned purchase decisions) for supermarket items were made in the store (Fam et al., 2011; Jantarat \& Shannon, 2016; Sigurdsson et al., 2010; Mohan et al., 2013), likely to be influenced by situational factors within the retail store environment (Sigurdsson et al., 2010).

Retailers as well as manufacturers have a strong interest in in-store marketing strategies, namely in-store promotions and price markdowns. In-store promotion would appeal to the hedonistic/impulse buyer, while price markdowns generate pleasure from a perceived deal (Fam et al., 2011). As such, other studies allege that in-store shopping environment was categorized into two separate effects: "the promotional effect", consisting of stimuli such as promotional discounts (coupons, multiple-item discounts, gifts, and sampling), and cheaper prices; and "the atmospheric engagement effect", which includes the stimuli of enjoyment, attractiveness, and satisfaction conveyed by in-store advertisements and displays (Jantarat \& Shannon, 2016; Zhou \& Wong, 2004; Kim et al., 2016). According to Kim et al. (2016) enjoyment and engagement positively influenced customers' satisfaction and intention to buy. 
Therefore, "the atmospheric engagement effect" (stimuli of enjoyment, attractiveness, and satisfaction) in terms of "in-store advertising" is the focus point in this research.

Moreover, strategies of product exhibition: end-of-aisle display stands layouts, product holders, and shelves (particularly in this study, to advertise a specific brand/product) are effective in enhancing purchase intentions by feeding and reinforcing the positive mental associations with the brand and product (Gabrielli \& Cavazza, 2014), and are related to this study aim in relation to "in-store advertising”. In consequence, in-store advertising denotes all the advertising media that consumers are dealing with in the retail stores' environments.

H3: General set of in-store creative advertisements have a stronger positive effect on the brand/product awareness and attitude than purchase intention.

H4: General set of in-store creative advertisements have a stronger positive effect on the brand awareness and attitude than product awareness and attitude.

H5: There is a significant difference between in-store and out-of-store creative advertisements, in terms of advertising effectiveness (consumers' attitude towards the advertised brand/product and purchase intention).

\section{Methodology}

In order to effectiveness evaluation of creative advertising on consumers' attitude towards the advertised brand/product, and purchase intentions two pre-tests and one main test were done. For choosing the research field in consideration to the significance of food industry, besides the competitive conditions in this industry's members and some particular features of this industry such as widely products distribution, high rate of everyday purchasing, and because of being low priced, also use-by dates, four of the largest (in the eye of product diversification and based on the experts' attitudes) and the most reputable food manufacturers in Iran were selected firstly. Afterwards, on the basis of the first pre-test, two of them finally were chosen as the selected manufacturing companies in this study.

Following this further, selecting the most impressive advertising method/medium, opinions of 20 wellexperienced experts in advertising, 100 purchasers, and 10 managers in the related industry were collected. In the first place, they were asked to mention the most influential and the most viewable advertising media based on their opinions. Then, after the answers categorizing, four media had placed 
in the highest priorities which were sent again to the experts owing to select only two media. Collecting the answers finally was reached the consensus on "stands" as the in-store advertising medium and "TV commercials" as the out-of-store. In the next stage, two different products from each of the two companies and five recent advertisements of each one the four products were selected. Therefore, 20 recent creative advertisements were chosen at first sight and ultimately, 12 advertisements (six stands and six TV commercials) as the most creative advertisements were selected for this study, according to 20 advertising experts' opinions.

\subsection{Sampling}

Concerning the target population, subsequently according to Cochran's formula determining the sample size in infinite population, the estimated sample size should be at least 273 people. This formula is used to calculate a sample size in a large population (Cochran, 1963). Therefore, announcement calling for participation in the field study in the Tehran major grocery stores/supermarkets was released randomly and harmoniously in all the main neighborhoods of the city in order to grab people attention, whereupon, 600 volunteers participated in the study.

Cochran's formula: $\mathrm{n}=\frac{\mathrm{p}(1-\mathrm{p}) \mathrm{z}^{2}}{\mathrm{e}^{2}} \mathrm{n}=\frac{.5 \times .5 \times(1.65)^{2}}{(.05)^{2}}$

\subsection{The first pre-study}

In the first step of the study simplification of the process and elimination of the brand familiarity's asymmetry effect which generates various mentality and decisions, four reputable large food manufacturers in Iran were chosen based on the experts' attitudes. In order to the brands awareness homogenization, one question in relation to brand recall was asked of 200 members of the sample population. Besides that, the selected products from all of the four brands (manufacturing companies) chose based on the breadth of their distribution in Tehran grocery stores/supermarkets. Additionally, approximate similarity of price, design, size and packaging were considered. The asked question was “To what extent do you know this particular brand?". The One Way (ANOVA) analysis on the answers with a scale range of " 1 " (I have not heard this brand name at all) to "10" (I know this brand name well) showed that two brands (of two different manufacturing companies) are better known for the respondents comparatively. Therefore, the two brands were chosen as the basis of this study. With 
regard to the level of significance at.00, the similarity existence between the levels of brands familiarity is rejected and dissimilarity between the levels of brands familiarity is accepted. The first and the third brands with the means of 8.24 and 7.78 , as such, the second and the forth brands with the means of 4.98 and 4.50 respectively, have been placed in the equal groups.

\subsection{The second pre-study}

With respect to the proven role of creativity in advertising effectiveness augmentation and more efficiency of creative ads in compared with non-creative ones. In order to simplification of the study circumstances, whereupon, more controlling on the research variables and enhancement of generalizability of the research, 10 advertisements chosen by the advertising experts were shown to the 100 participants and they were asked to rank the advertisements with a scale range of 0 to 100 based on their creativity. Since this study purpose is to evaluate of the perceived creativity level by the target group, not only the level of creativity of advertisements in the eye of advertisements' successfulness or failure. Moreover, creativity criteria measurement is not the aim of this study, but rather, a general and simple scale was chosen instead. According to some other research (Baack et al., 2008; Baack et al., 2016) in this study also a single-item scale to the perceived creativity measurement was used. As mentioned, many research approved this scale, for instance "Ample evidence exists to support the legitimate use of single-item measures operationalize a focal construct, while also capturing other important advantages" (Fisher, Matthews \& Gibbons, 2016; Baack et al., 2016; Gardner, Cummings, Dunham \& Pierce, 1998). "Not only did the scale help simplify the process of evaluating creativity, it reduced respondent burden and thereby increased the likelihood of participation. Single-item measures are also short, easy to administer, are less time consuming and not monotonous to complete, thus reducing response biases" (Fisher et al., 2016; Baack et al., 2016; Gardner et al., 1998). "In summary, the single-item scale to measure creativity has been used successfully in several academic studies and it contributes to higher levels of response. After presenting a brief definition of creativity, each respondent scored the ad for its degree of creativity on a scale of 0 to 100, with 100 representing a highly creative ad" (Baack et al., 2008; Till \& Baack, 2005).

In the end, the creativity scores ranged from 30 to 95 with a mean score of 62.6. Then, a mean split of the creativity scores was taken for all ads and created two categories (low and high creativity). Afterwards, four advertisements were selected merely as the most creative ones in order to be examined in this study. 


\subsection{Product display}

The study fields formed based on two end-of-aisle stands displaying the product picture, each stand dedicated to a particular product and brand were placed in the stores. On the other hand, two TV commercials were aired during one of the most popular and most viewed TV programmes, within a 20minute interval each.

\subsection{Depending variable and reliability}

Measuring the study dependent variables, hereunder questions were asked according to table1. In order to test the reliability, in consideration to previous research confirmatory factor analysis of the same questions (Janssens \& Pelsmacker, 2005), the questions sets' Cronbach's alphas, were calculated (see Table 1). Clearly then, as the all obtained above .7, the questions' reliability is acceptable (Nunnally, 1987; Panayides, 2013). In addition, for variables measurement the Likert 7 point scale was used.

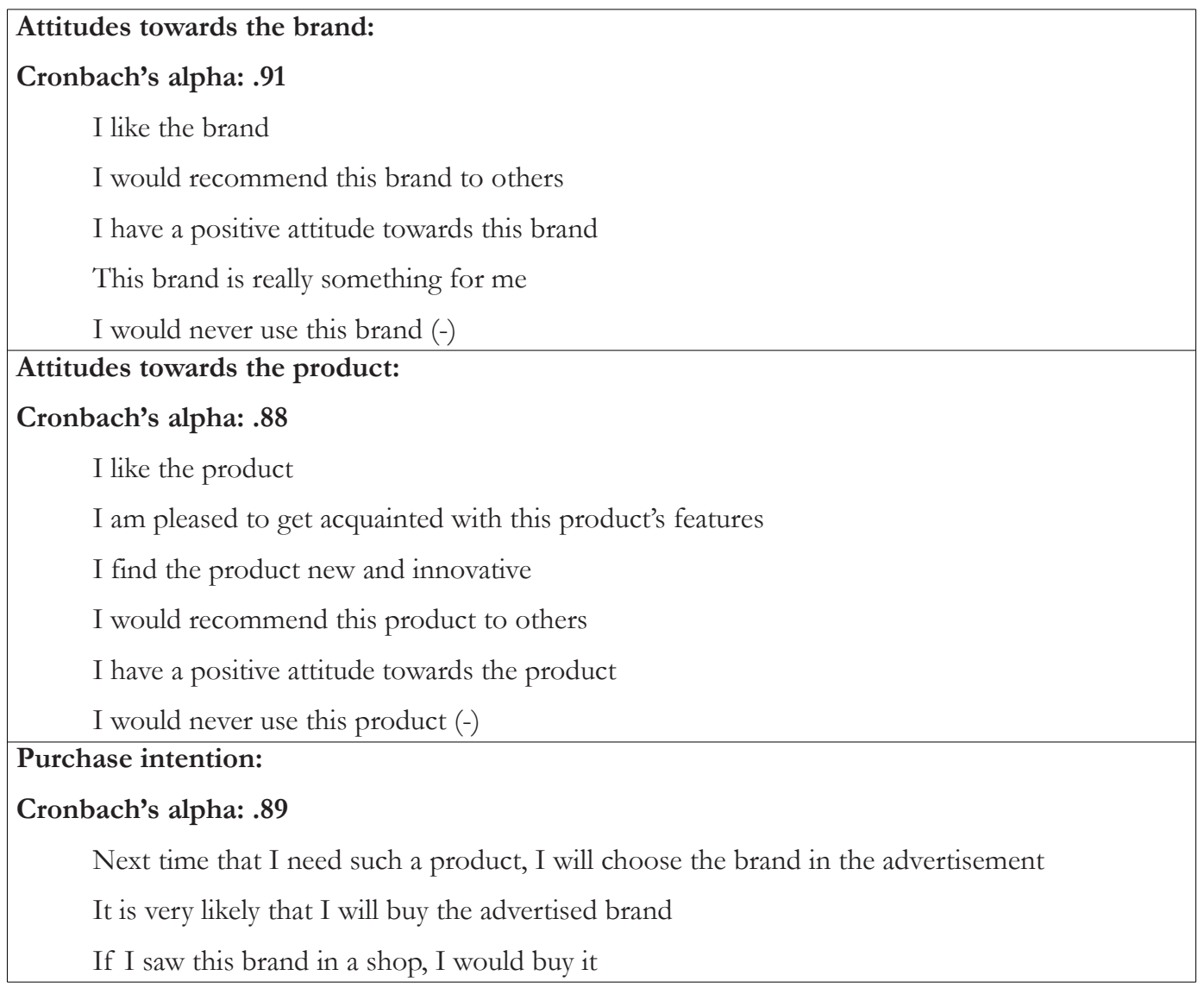

Table 1. Measurement of the dependent variables and questions scale's reliability 


\subsection{Method bias}

Measuring method bias in the second pre-study, a non-creative advertisement totally unrelated to this survey selected brands (TV commercial) was shown to participants for measuring the study dependent variables (attitude towards brand, product and purchase intention). Paired samples t-test in order to examine the test results was used. In the face of the method bias existence, participants should have perceived a positive attitude towards the variables. Whereas, in an under controlled conditions should not occur this for such an advertisement. Comparing the results before and after watching the advertisement does not show any method bias in the survey process. The results in relation to the advertisement, based on the Paired Samples Test are as following: attitudes towards the brand (before: 5.45, after: 5.50, sig:.21), attitudes towards the product (before: 4.23, after: 4.34, sig:.68), purchase intention (before: 4.15, after: 4.30, sig:.45).

\subsection{Main study}

In the main study, the 600 participants (members of the sample population) were divided into two 300member separated groups; after all, 588 participants finished the survey process to great effect. One group firstly was exposed to the in-store advertisements and then to the out of stores advertisements and the contrary of this process was conducted for the second group. Choosing this process was to test the participants' biases in the second step of responding. Finally, comparing the two groups using the independent sample t-test confirms $\mathrm{H} 0$ regarding the significance level at.35 (more than.05), indicating harmony of answers means between two groups and proofing the data gathering in this stage was biasfree. Answering the questions process had two steps; the first step before exposing the advertisements and the second, after watching them, to make a comparison between participants' attitudes and measuring the changes in variables' means before and after watching the advertisements. The questionnaire was consisted of four separated questions' parts. The questions related to attitudes towards the brand, attitudes towards the product, purchase intention, and the fourth part was pertained to participants' demographic information. In the survey related to in-store advertising, participants were asked to answer the questionnaires, after that, purchase the goods what they need and had already the intention of buying. It should be considered that the target end-of-aisle stands were not mentioned to them. After their shopping, they were asked again to answer the questionnaires. In respect of out-ofstore advertising also the participants were asked to watch one of the most popular and most viewed TV programmes at a particular time. Then, the two considered TV commercials were aired during the 
programme within a 20-minute interval for each one. Thereafter, the participants answered the questionnaires in conformity with the previous procedure in two steps.

\section{Results}

The age range of the participants in this survey is 25 to 65 years old. Demographic information of the study participants shows that $58 \%$ of them were male and $42 \%$ were female. In the view of education level $5 \%$ of them were holders of Ph.D., 25\% Master's degree, $60 \%$ Bachelor's, and 10\% associate's degree or high school diploma.

In order to measure the hypotheses, one-sample t-test and paired sample t-test were applied. The means significance differences and acceptance or rejection of the hypotheses were examined on the basis of the tests. In consideration to the obtained significance level that all are less than .05, with confidence level at 95\%, differences between the means are significant. Following this, for measuring the influence of advertising towards the brand and product attitudes, moreover, purchase intention after watching the target advertisements, the stands and TV commercials attained means were examined. In relation to out-of-store advertising, changes in the means' figures related to attitudes towards the brand, product, and purchase intention respectively as following: $1.24, .71$, and .57 , and in respect of in-store advertising also the means are as: $.38, .53$, and 1.32 . Therefore, from the obtained results and in the view of intensity level of influence, out-of-store (creative) advertising has the most influence on attitude towards the advertised brand, then on the advertised product, and lastly on the purchases intention respectively. Conversely, in-store (creative) advertising has the most influence firstly on the purchase intention, then on attitude towards the advertised product and subsequently, on the advertised brand. On this basis, only the first and the second hypotheses of this survey are accepted.

Concerning the fifth hypothesis and according to the results of one-sample t-test (see Table 2), in relation to attitude towards the advertised brand and purchase intention in reference to the significance level at .00 and 95\% of confidence level, it is clear that the attained means' differences resulted from the participants' answering in regard to in-store and out-of-store advertising are significant. Whereas, from the standpoint of attitude towards the advertised product, regarding the significance level at .52, H0 has been accepted, besides, with confidence level at 95\% the hypothesis suggested harmony existence between the two groups' means is accepted. Accordingly, one part of the fifth hypothesis is accepted and the other side is rejected. 


\begin{tabular}{|c|c|c|c|c|c|c|}
\hline & \multirow[t]{2}{*}{$\mathrm{t}$} & \multirow[t]{2}{*}{ df } & \multirow{2}{*}{$\begin{array}{l}\text { Sig. (2- } \\
\text { tailed) }\end{array}$} & \multirow{2}{*}{$\begin{array}{c}\text { Mean } \\
\text { Difference }\end{array}$} & \multicolumn{2}{|c|}{$\begin{array}{l}\text { 95\% Confidence Interval of the } \\
\text { Difference }\end{array}$} \\
\hline & & & & & Lower & Upper \\
\hline Brand $2($ Test Value $=5.94)$ & -15.20 & 587 & .00 & -.85 & -.97 & -.75 \\
\hline Product 2 (Test Value $=4.41)$ & -1.06 & 587 & .28 & -.06 & -.18 & .05 \\
\hline Purchase 2 (Test Value $=4.69)$ & 9.86 & 587 & .00 & .55 & .44 & .67 \\
\hline
\end{tabular}

The test values are equal to the obtained means of respondents' attitudes after viewing the out-of-store advertisements

Brand $2=$ Attitude towards the brand after viewing the in-store advertisements

Product2 = Attitude towards the product after viewing the in-store advertisements

Purchase $2=$ Purchase intention after viewing the in-store advertisements

Table 2. The results of one-sample t-test pertain to the fifth hypothesis examination (the differences between in-store and out-of-store advertising results)

\section{Discussion and implications for practice}

In this survey, three factors were examined owing to understanding the consumer behaviour and attitude towards the in-store and out-of-store advertising (their attitudes towards the brand, towards the product, and their purchase intention).

The results examining the first two hypotheses from the stand point of intensity level of influence show that out-of-store (creative) advertising has influence primarily on attitude towards the advertised brand, then on attitude towards the advertised product, and finally on the purchases intention. On the other hand, examining the two next hypotheses indicate that in-store (creative) advertising, firstly has influence on the purchase intention, then on attitude towards the advertised brand, and lastly on attitude towards the advertised product.

The results of the fifth hypothesis examining also show an obvious significant difference between attitude towards the advertised brand and purchase intention in out-of-store and in-store advertising, whereas, in the light of attitude towards the advertised product, there is no significant difference between the two types of advertising media. On a lighter note, a creative out-of-store ad in the first place leads to branding. In contrast, in regard to the in-store ads the purchase intention is the first outcome of a creative advertising. These findings are complied with many other research claims such as Luxton and Drummond (2000), that suggest "outdoor (out-of-store) advertising is largely used for branding support and not primarily as a tool to increase product purchases in the short run", also the results of Jurca and Madlberger study (2015) that alleges "outdoor/ambient (out-of-store) advertising campaigns seek to strengthen consumers' outlooks instead of increasing sales in the short run, however, should show a positive impact on sales in the long run". As such, based on other studies "around two-thirds of brand/product decisions for supermarket items were made in the store" (Fam et al., 2011; Jantarat \& Shannon, 2016; Sigurdsson et al., 2010; Mohan et al., 2013). In the meantime, the 
current survey findings confirm the Gabrielli and Cavazza argument (2014) representing "strategies of product exhibition (in-store-advertising) are effective in enhancing purchase intentions by feeding and reinforcing the positive mental associations with the brand and product".

In final analysis, as was noted previously, with increased exposure to advertising, consumers are getting fed up with marketers' repetitive and boring persuasion techniques, therefore, consumers oftentimes try to avoid advertisements (Hutter, 2015). Hence, devising the new creative advertising strategies gaining and holding consumers' attention in order to raise the advertising effectiveness, and increase the sales amount is a vital issue in strategic marketing. To that end, creativity plays a significant role as the heart of advertising effectiveness (Bernardin et al., 2008; Lee \& Hong, 2016; Baack et al., 2016). Besides, was mentioned the effectiveness means having likable ads can result in greater brand awareness, more favorable attitudes towards the brand/product, and stronger behavioural/purchase intentions (Baack et al., 2016; Till \& Baack, 2005). Accordingly, marketing and advertising experts, moreover, manufacturers and retailers have to pay more attention to the main purpose of advertising in order to maximize its effectiveness. In other words, they should determine the advertising major aim between enhancing the brand awareness, product awareness, and purchase intention in order to choose an appropriate medium. On the other hand, creativity based on reviewing the literature, is a highly vital factor to consider in (promotional) marketing, branding, and advertising strategy devising.

As the field for future studies, examining this research in other cultures and industries or by other methods could generate a comparable result. 


\section{References}

Ahn, J., Lee, C., Lee, J., \& Paik, M. (2012). An analysis of different types of advertising media and their influence on consumer preferences and purchase intentions for digital cameras. Journal of Global Scholars of Marketing Science, 22(4), 356-369. https://doi.org/10.1080/21639159.2012.721212

Akören, A.N. (2015). Interaction of Outdoor Advertising Improved by Innovative Methods with Digital Art. Procedia - Social and Behavioral Sciences, 195, 799-805.

https://doi.org/10.1016/j.sbspro.2015.06.178

Ang, S.H., Lee, Y.H., \& Leong, S.M. (2007). The ad creativity cube: conceptualization and initial validation. Journal of the Academy of Marketing Science, 35(2), 220-232. https://doi.org/10.1007/s11747-007$0042-4$

Areni, C.S., \& Miller, R. (2012). Sales effects of in-store radio advertising. Journal of Marketing Communications, 18(4), 285-295. https://doi.org/10.1080/13527266.2010.528208

Baack, D.W., Wilson, R.T., \& Till, B.D. (2008). Creativity and Memory Effects: Recall, Recognition, and an Exploration of Nontraditional Media. Journal of Advertising, 37(4), 85-94. https://doi.org/10.2753/JOA0091-3367370407

Baack, D.W., Wilson, R.T., Van Dessel, M.M., \& Patti, C.H. (2016). Advertising to businesses: Does creativity matter?. Industrial Marketing Management, 55, 169-177.

https://doi.org/10.1016/j.indmarman.2015.10.001

Bae, S.-W., Wright, L.B., \& Taylor, R.D. (2001). Print Advertising Context Effects. Journal of Promotion Management, 6(1-2), 73-88. https://doi.org/10.1300/J057v06n01_08

Bernardin, T., Kemp-Robertson, P., Stewart, D.W., Cheng, Y., Wan, H., Rossiter, J.R. et al. (2008). Envisioning the Future of Advertising Creativity Research: Alternative Perspectives. Journal of Advertising, 37(4), 131-150. https://doi.org/10.2753/JOA0091-3367370411

Besana, A., \& Clavenna, V. (2012). Advertising and Branding of Italian Visual Arts at 'Hard Times'. Procedia Economics and Finance, 1, 41-50. https://doi.org/10.1016/S2212-5671(12)00007-X

Buil, I., Chernatony, L.D., \& Martínez, E. (2013). Examining the role of advertising and sales promotions in brand equity creation. Journal of Business Research, 66(1), 115-122. https://doi.org/10.1016/j.jbusres.2011.07.030 
Clement, J. (2007). Visual influence on in-store buying decisions: An eye-track experiment on the visual influence of packaging design. Journal of Marketing Management, 23(9-10), 917-928. https://doi.org/10.1362/026725707X250395

Cochran, W.G. (1963). Sampling Techniques (2nd ed.). New York: Wiley.

Fam, K.S., Merrilees, B., Richard, J.E., Jozsa, L., Li, Y., \& Krisjanous, J. (2011). In-store marketing: A strategic perspective. Asia Pacific Journal of Marketing and Logistics, 23(2), 165-176. https://doi.org/10.1108/13555851111120470

Fisher, G.G., Matthews, R.A., \& Gibbons, A.M. (2016). Developing and investigating the use of singleitem measures in organizational research. J Occup Health Psychol, 21(1), 3-23. https://doi.org/10.1037/a0039139

Gabrielli, V., \& Cavazza, N. (2014). The influence of in-store product holders on orientation towards the product and on purchase intention. The International Review of Retail, Distribution and Consumer Research, 24(3), 311-327. https://doi.org/10.1080/09593969.2013.862507

Gardner, D.G., Cummings, L.L., Dunham, R.B., \& Pierce, J.L. (1998). Single-Item Versus Multiple-Item Measurement Scales: An Empirical Comparison. Educational and Psychological Measurement, 58(6), 898-915. https://doi.org/10.1177/0013164498058006003

Hartnett, N., Romaniuk, J., \& Kennedy, R. (2016). Comparing direct and indirect branding in advertising. Australasian Marketing Journal (AMJ), 24(1), 20-28. https://doi.org/10.1016/j.ausmj.2015.12.002

Hutter, K. (2015). Unusual location and unexpected execution in advertising: A content analysis and test of effectiveness in ambient advertisements. Journal of Marketing Communications, 21(1), 33-47. https://doi.org/10.1080/13527266.2014.970823

Islam, J.U., \& Rahman, Z. (2016). Examining the effects of brand love and brand image on customer engagement: An empirical study of fashion apparel brands. Journal of Global Fashion Marketing, 7(1), 45-59. https://doi.org/10.1080/20932685.2015.1110041

Janssens, W., \& De Pelsmacker, P. (2005). Advertising for New and Existing Brands: The Impact of Media Context and Type of Advertisement. Journal of Marketing Communications, 11(2), 113-128. https://doi.org/10.1080/1352726042000306847

Jantarat, J., \& Shannon, R. (2016). The moderating effects of in-store marketing on the relationships between shopping motivations and loyalty intentions. The International Review of Retail, Distribution and Consumer Research, 26(5), 1-23. https://doi.org/10.1080/09593969.2016.1159242 
Jurca, M.A., \& Madlberger, M. (2015). Ambient advertising characteristics and schema incongruity as drivers of advertising effectiveness. Journal of Marketing Communications, 21(1), 48-64. https://doi.org/10.1080/13527266.2014.970824

Kim, H.-Y., Lee, J.Y., Mun, J.M., \& Johnson, K.K.P. (2016). Consumer adoption of smart in-store technology: Assessing the predictive value of attitude versus beliefs in the technology acceptance model. International Journal of Fashion Design, Technology and Education, 10(1), 26-36. https://doi.org/10.1080/17543266.2016.1177737

Koeck, R., \& Warnaby, G. (2014). Outdoor advertising in urban context: spatiality, temporality and individuality. Journal of Marketing Management, 30(13-14), 1402-1422. https://doi.org/10.1080/0267257X.2014.909869

Lee, J., \& Hong, I.B. (2016). Predicting positive user responses to social media advertising: The roles of emotional appeal, informativeness, and creativity. International Journal of Information Management, 36(3), 360-373. https://doi.org/10.1016/j.ijinfomgt.2016.01.001

Lehnert, K., Till, B.D., \& Ospina, J.M. (2014). Advertising Creativity: The Role of Divergence Versus Meaningfulness. Journal of Advertising, 43(3), 274-285. https://doi.org/10.1080/00913367.2013.851630

Luxton, S., \& Drummond, L. (2000). What is this thing called Ambient Advertising? Paper presented at the ANZMAC (Aust \& New Zealand Marketing Academy Conference): Visionary Marketing for the 21st Centry: Facing the Challenge), Australia.

Maclnnis, D.J., \& Jaworski, B.J. (1989). Information Processing From Advertisements: Toward an Integrative Framework. Journal of Marketing, 53, 1-23. https://doi.org/10.2307/1251376

Maniu, A.-I., \& Zaharie, M.-M. (2014). Advertising Creativity - The Right Balance between Surprise, Medium and Message Relevance. Procedia Economics and Finance, 15, 1165-1172. https://doi.org/10.1016/S2212-5671(14)00573-5

Mohan, G., Sivakumaran, B., \& Sharma, P. (2013). Impact of store environment on impulse buying behavior. European Journal of Marketing, 47(10), 1711-1732. https://doi.org/10.1108/EJM-03-2011-0110

Nunnally, J.C. (1978). Assessment of reliability. Psychometric Theory (2nd ed.). New York: McGraw-Hill.

Panayides, P. (2013). Coefficient alpha. Europe's Journal of Psychology, 9(4), 687-696. https://doi.org/10.5964/ejop.v9i4.653

Sasser, S.L., \& Koslow, S. (2008). Desperately Seeking Advertising Creativity: Engaging an Imaginative "3Ps" Research Agenda. Journal of Advertising, 37(4), 5-20. https://doi.org/10.2753/JOA0091-3367370401 
Sigurdsson, V., Engilbertsson, H., \& Foxall, G. (2010). The Effects of a Point-of-Purchase Display on Relative Sales: An In-Store Experimental Evaluation. Journal of Organizational Behavior Management, 30(3), 222-233. https://doi.org/10.1080/01608061.2010.499028

Smith, R.E., Chen, J., \& Yang, X. (2008). The Impact of Advertising Creativity on the Hierarchy of Effects. Journal of Advertising, 37(4), 47-62. https://doi.org/10.2753/JOA0091-3367370404

Smith, R.E., MacKenzie, S.B., Yang, X., Buchholz, L.M., \& Darley, W.K. (2007). Modeling the Determinants and Effects of Creativity in Advertising. Marketing Science, 26(6), 819-833. https://doi.org/10.1287/mksc.1070.0272

Smith, R.E., \& Yang, X. (2004). Toward a General Theory of Creativity in Advertising: Examining the Role of Divergence. Marketing Theory, 4(1-2), 31-58. https://doi.org/10.1177/1470593104044086

Song, P., Xu, H., Techatassanasoontorn, A., \& Zhang, C. (2011). The influence of product integration on online advertising effectiveness. Electronic Commerce Research and Applications, 10(3), 288-303. https://doi.org/10.1016/j.elerap.2010.09.003

Till, B.D., \& Baack, D.W. (2005). Recall and Persuasion: Does Creative Advertising Matter?. Journal of Advertising, 34(3), 47-57. https://doi.org/10.1080/00913367.2005.10639201

Umit Kucuk, S. (2011). Push-based brand awareness: The role of product availability and in-store merchandising. The International Review of Retail, Distribution and Consumer Research, 21(3), 201-213. https://doi.org/10.1080/09593969.2011.578793

Vianelli, D., Dianoux, C., Domanski, T., \& Herrmann, J.L. (2007). In-Store Shopping Behavior. Journal of East-West Business, 13(2-3), 115-142. https://doi.org/10.1300/J097v13n02_02

Wang, X., \& Yang, Z. (2010). The Effect of Brand Credibility on Consumers' Brand Purchase Intention in Emerging Economies: The Moderating Role of Brand Awareness and Brand Image. Journal of Global Marketing, 23(3), 177-188. https://doi.org/10.1080/08911762.2010.487419

West, D.C., Kover, A.J., \& Caruana, A. (2008). Practitioner and Customer Views of Advertising Creativity: Same Concept, Different Meaning?. Journal of Advertising, 37(4), 35-46. https://doi.org/10.2753/JOA0091-3367370403

Wilson, R.T., Baack, D.W., \& Till, B.D. (2015). Creativity, attention and the memory for brands: An outdoor advertising field study. International Journal of Advertising, 34(2), 232-261. 
Yang, X., \& Smith, R.E. (2009). Beyond Attention Effects: Modeling the Persuasive and Emotional Effects of Advertising Creativity. Marketing Science, 28(5), 935-949.

https://doi.org/10.1287/mksc.1080.0460

Zenetti, G., \& Klapper, D. (2016). Advertising Effects Under Consumer Heterogeneity - The Moderating Role of Brand Experience, Advertising Recall and Attitude. In Press. https://doi.org/10.1016/j.jretai.2016.02.004

Zhou, L., \& Wong, A. (2004). Consumer Impulse Buying and In-Store Stimuli in Chinese Supermarkets. Journal of International Consumer Marketing, 16(2), 37-53.

https://doi.org/10.1300/J046v16n02_03

Intangible Capital, 2017 (www.intangiblecapital.org)

Article's contents are provided on an Attribution-Non Commercial 3.0 Creative commons license. Readers are allowed to copy, distribute and communicate article's contents, provided the author's and Intangible Capital's names are included. It must not be used for commercial purposes. To see the complete license contents, please visit http://creativecommons.org/licenses/by-nc/3.0/. 